This template is provided to give authors a basic shell for preparing your manuscript for submittal to a meeting or event. Styles have been included to give you a basic idea of how your finalized paper will look before it is published. All manuscripts submitted will be extracted from this template and tagged into an XML format; standardized styles and fonts will be used when laying out the final manuscript. Links will be added to your manuscript for references, tables, and equations. Figures and tables should be placed directly after the first paragraph they are mentioned in. The content of your paper WILL NOT be changed.

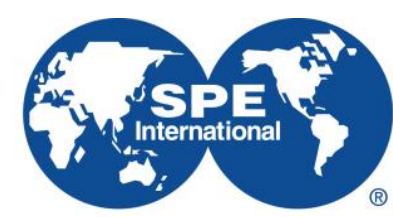

Society of Petroleum Engineers

\title{
SPE-186884-MS
}

\section{Revisiting EOR Projects in Indonesia through Integrated Study: EOR Screening, Predictive Model, and Optimisation}

A.D. Hartono, Kyushu University; F. Hakiki, King Abdullah University of Science and Technology; Z. Syihab, Institut Teknologi Bandung; F. Ambia, SKK Migas; A. Yasutra, S. Sutopo, Institut Teknologi Bandung; M. Efendi, V. Sitompul, I. Primasari, R. Apriandi, Pertamina Upstream Technology Center

This paper was selected for presentation by an SPE program committee following review of information contained in an abstract submitted by the author(s). Contents of the paper have not been reviewed by the Society of Petroleum Engineers and are subject to correction by the author(s). The material does not necessarily reflect any position of the Society of Petroleum Engineers, its officers, or members. Electronic reproduction, distribution, or storage of any part of this paper without the written consent of the Society of Petroleum Engineers is prohibited. Permission to reproduce in print is restricted to an abstract of not more than 300 words; illustrations may not be copied. The abstract must contain conspicuous acknowledgment of SPE copyright.

\section{Abstract}

EOR preliminary analysis is pivotal to be performed at early stage of assessment in order to elucidate EOR feasibility. This study proposes an in-depth analysis toolkit for EOR preliminary evaluation. The toolkit incorporates EOR screening, predictive, economic, risk analysis and optimisation modules. The screening module introduces algorithms which assimilates statistical and engineering notions into consideration. The United States Department of Energy (U.S. DOE) predictive models were implemented in the predictive module. The economic module is available to assess project attractiveness, while Monte Carlo Simulation is applied to quantify risk and uncertainty of the evaluated project. Optimization scenario of EOR practice can be evaluated using the optimisation module, in which stochastic methods of Genetic Algorithms (GA), Particle Swarm Optimization (PSO) and Evolutionary Strategy (ES) were applied in the algorithms. The modules were combined into an integrated package of EOR preliminary assessment. Finally, we utilised the toolkit to evaluate several Indonesian oil fields for EOR evaluation (past projects) and feasibility (future projects). The attempt was able to update the previous consideration regarding EOR attractiveness and open new opportunity for EOR implementation in Indonesia.

Keywords: Integrated EOR Study; Preliminary EOR; EOR Screening; Predictive Model; Economic Analysis; Risk and Uncertainty Evaluation; Optimization; Stochastic Methods; Genetic Algorithm (GA); Particle Swarm Optimization (PSO); Evolutionary Strategy (ES).

\section{Introduction}

Amongst several categories of fossil resources, oil is one of the most vital. It is crucial to maintaining the continuity of oil production to satisfy energy demands. Nevertheless, there lie considerable challenges to meet this objective since the majority of worldwide oil reservoirs nowadays are mature stage. The 
supplementary recovery schemes known as the Enhanced Oil Recovery (EOR) have been proposed to improve oil production from those mature reservoirs to address this issue.

Implementation of EOR technology requires thorough investigations and involves several assessment stages (Dickson et al. 2010; Abu El Ela et al. 2014; Abdurrahman et al. 2016). Figure 1 illustrates the complete EOR assessments workflow. This study focuses on the preliminary assessment stage of EOR. Conducting the primary EOR assessment is at an early stage of EOR analysis to gain prior information regarding feasibility and attractiveness of EOR implementation in the reservoir of interest. This phase commonly incorporates screening, reservoir performance prediction and economic evaluations. Investigators have proposed several different schemes to support this stage of analysis (Al Bahar et al. 2004; Hon et al. 2007; Dickson et al. 2010).

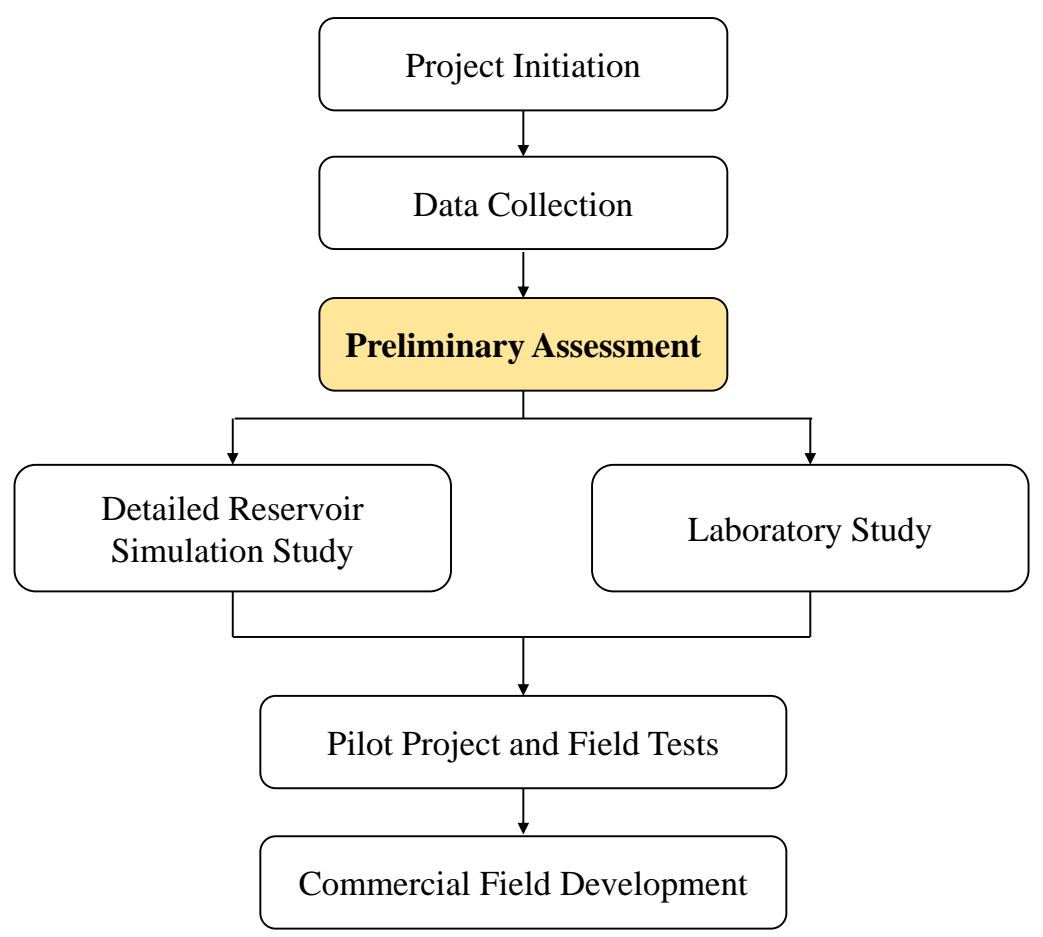

Figure 1. The General EOR Assessment Workflow.

This paper aims to update the previous consideration regarding EOR attractiveness and open new opportunity for EOR implementation in Indonesia. This work proposes a scheme to EOR primary assessment by including risk and uncertainty analysis complemented by optimisation scenario to the general workflow of EOR preliminary screening. EOR screening evaluation is an attempt of identifying the most appropriate EOR method for a given reservoir (Dickson et al. 2010) while simultaneously rule out unfeasible EOR options (Taber et al. 1997a, 1997b).

Figure 2 displays the updated workflow of EOR preliminary screening evaluation proposed by our investigation. A total of five modules, each represents a phase in EOR preliminary assessment, has been developed and linked together into an integrated package. The package is not only capable of assisting engineers to identify EOR feasibility at early stage of analysis, but also establishes better guidance for further assessment stages. The toolkit was used to re-evaluate several oil fields in Indonesia from past projects both success and failure. This endeavour also updates the preceding perspectives about EOR prospect, thus opens a new opportunity to implement EOR in several Indonesian oil fields. 


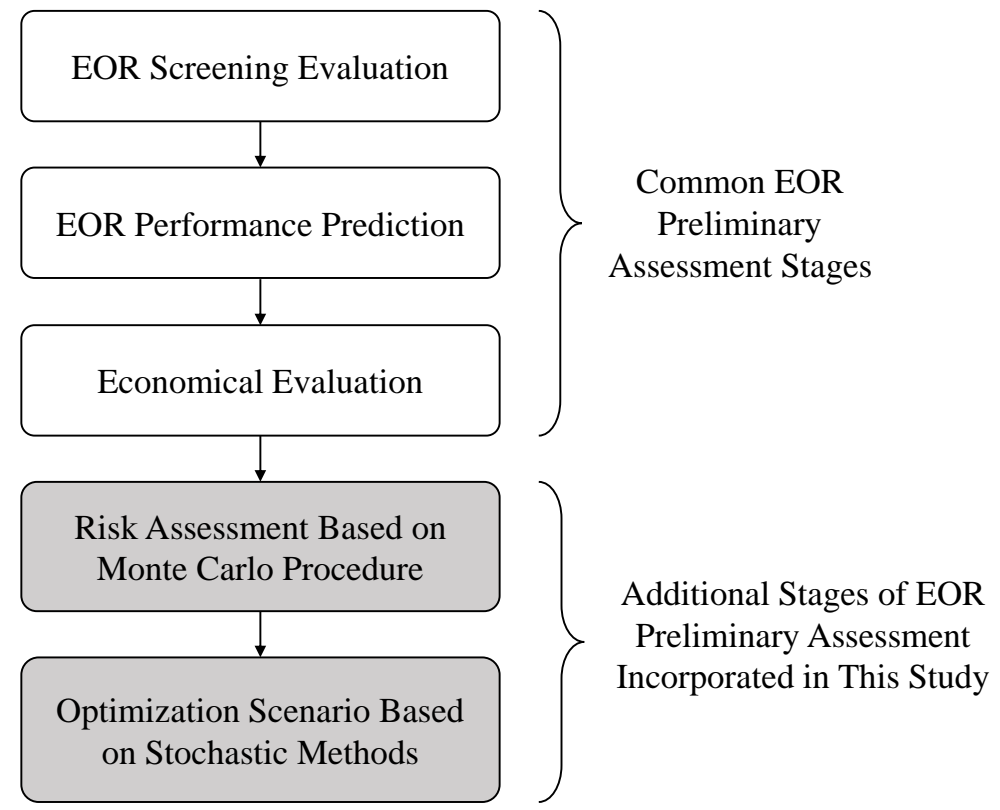

Figure 2. The Proposed EOR Assessment Workflow of Current Study.

\section{Methods}

\subsection{EOR Screening}

This study introduces a new procedure to perform EOR screening study by integrating statistical and engineering perspectives. A detailed algorithm could be found in the literature (Hartono et al. 2017). The implementation of the algorithm is built as an in-house software so repetitive works could easily be executed (Hartono et al. 2017).

The initial step of EOR screening evaluation is to construct the selection criteria database which lists the interval of reservoir and fluid properties that likely to yield successful implementation of a particular EOR method (Taber et al. 1997a, Taber et al. 1997b, Dickson et al. 2010, Al Adasani and Bai 2011). The screening criteria was based on combination of the characteristics of successful EOR projects worldwide and understanding of the fundamental mechanisms of oil displacement (Taber et al. 1997a). The methods is to combine the screening criteria reported by earliest literature in EOR database (Taber et al. 1997a, $1997 b$ ) with more recent data noted by later database (Al Adasani and Bai, 2010, 2011) in order to develop a thorough database which captures worldwide EOR projects from 1974 until 2010 (See Table A1 in Appendix). We incorporate fifteen EOR methods together with eight reservoir and fluid properties in the database. Table 1 displays the list of reservoir properties included in the study, while the incorporated EOR methods are shown in Table 2.

Table 1. Reservoir and Fluid Properties Incorporated in the Study.

\begin{tabular}{|cc|}
\hline .Reservoir and Fluid Properties & Units/Options \\
\hline Oil API Gravity & ${ }^{\circ} \mathrm{API}$ \\
Oil Viscosity & $\mathrm{cP}$ \\
Reservoir Porosity & $\%$ \\
Oil Saturation at Initial Flooding Condition & $\%$ \\
Depth & $\mathrm{ft}$ \\
Reservoir Temperature & ${ }^{\circ} \mathrm{F}$
\end{tabular}


Reservoir Permeability

Reservoir Formation Type
$\mathrm{mD}$

Options: Sandstone or Carbonate

Table 2. EOR Methods Incorporated in the Study.

\begin{tabular}{|cc|}
\hline EOR Methods Classification & Detailed EOR Methods \\
\hline & $\mathrm{CO}_{2}$ \\
Miscible Gas Methods & Hydrocarbon \\
& Nitrogen \\
& Water Alternating Gas (WAG) \\
\hline Immiscible Gas Methods & $\mathrm{CO}_{2}$ \\
& Hydrocarbon \\
& Nitrogen \\
\hline Chemical Methods & Hydrocarbon Water Alternating Gas (HWAG) \\
& Polymer \\
& Surfactant-Polymer (SP) \\
& Alkaline-Surfactant-Polymer (ASP) \\
\hline Thermal Methods & Steam Flood \\
& In-Situ Combustion \\
& Hot Water \\
\hline Microbial Methods & Microbial \\
\hline
\end{tabular}

The subsequent step is to develop algorithms to assess EOR feasibility. The underlying principle of the algorithms is to consider the relative position of each of the single-valued input properties of the given reservoir against their respective screening criteria of every EOR methods listed in the database. We assume that each of the screening criteria properties listed in the database, with an exception for reservoir formation type property, follows a certain continuous probability distribution form. This premise was the cornerstone of the proposed screening methodology.

Eventually, the EOR methods are ranked in descending order based on their pertinent total fitness scores. Figure 3 demonstrates the general workflow of the proposed screening algorithms. The algorithms were further classified into single-value and distribution-value input algorithms. Single-value input is the scenario in which the input properties of a given reservoir is in the form of single-value that represents the entire values of the pertinent distribution. A single value of permeability, porosity, oil viscosity, reservoir depth and temperature are instances of single-value input category. We introduced the terms average-, minimum-, and maximum-type property to refer to probability density function (pdf) form: triangle, rightskewed trapezoid, and left-skewed trapezoid respectively (Hartono et al. 2017; also see Figure 4). 


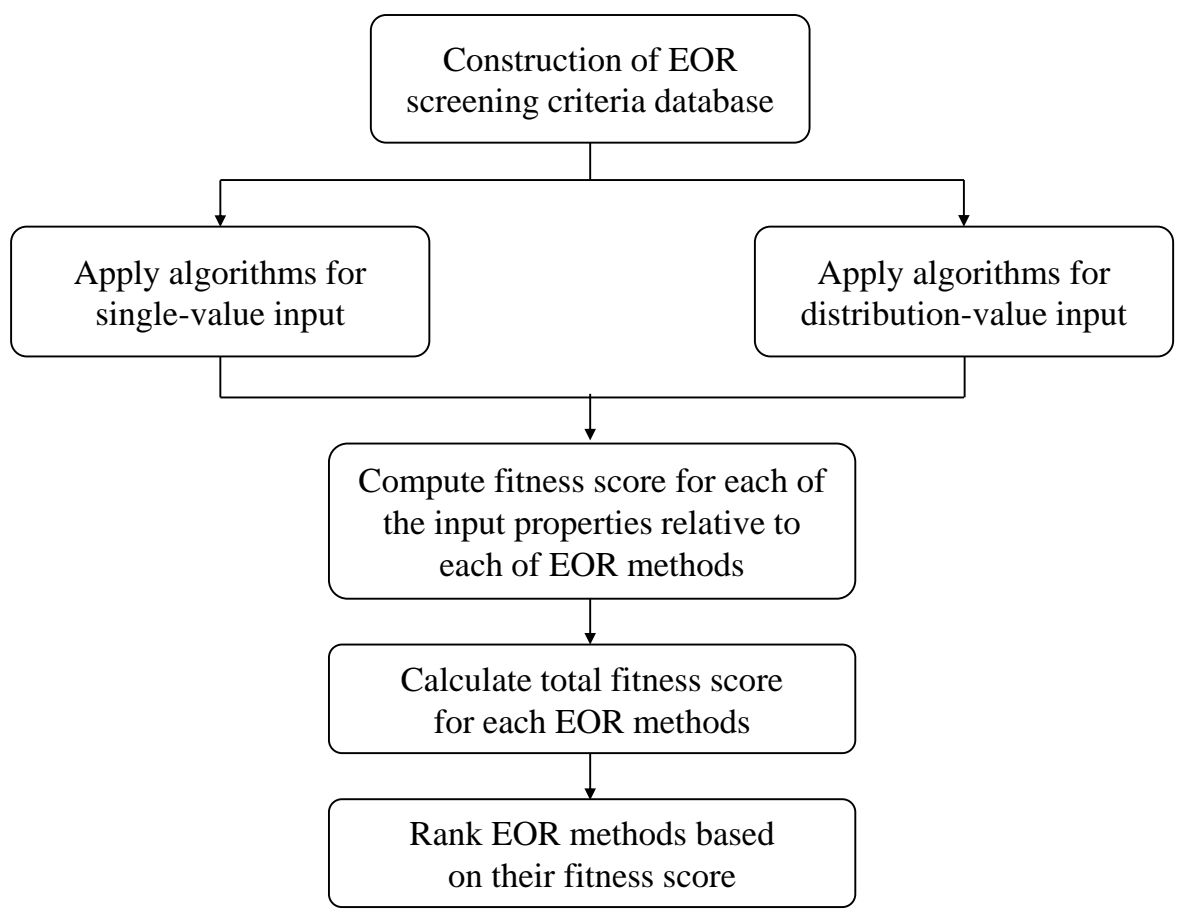

Figure 3. The General Workflow of the Screening Algorithm.

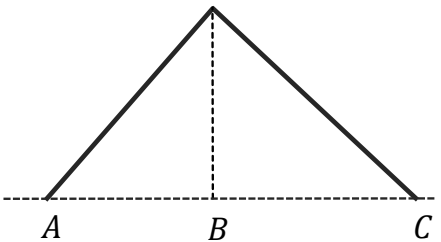

(i)

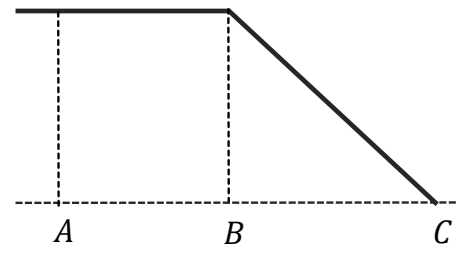

(ii)

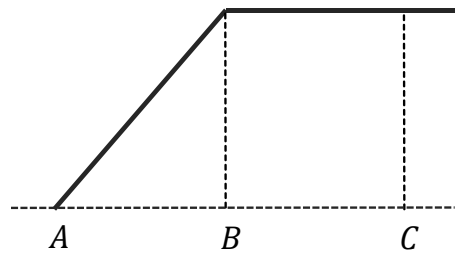

(iii)

$A=$ the minimum value of a reservoir property

$B=$ the average value of a reservoir property

$C=$ the maximum value of a reservoir property

Figure 4. The Continuous Distribution Form of the (i) Average-, (ii) Minimum-, and (iii) Maximum-Type.

\subsubsection{Screening Algorithm for Single-Value Input}

Single-value input is a scenario in which the input properties of a given reservoir may be forced as a single value: permeability, porosity, oil viscosity, reservoir depth and temperature. Integration of statistical and engineering consideration is the science behind it. Figure 4 depicts a graphical conception of the concept. Table A2 of Appendix explicates the default configuration of property classification in screening criteria.

The initial step of the single-value screening algorithms is to determine whether the single-value input property falls within or outside the distribution interval. A cut-off parameter $\alpha$ is introduced in order to specify fitness scores to the minimum and maximum values of the distributions, respectively for those properties fall within their respective distribution intervals. A geometrical point of view would have a cutoff value that transforms original distribution into their pertinent pseudo-distribution forms. The pseudo- 
distribution forms depend on the respective classification of properties. Figure 5 presents a graphical representation of the notion.

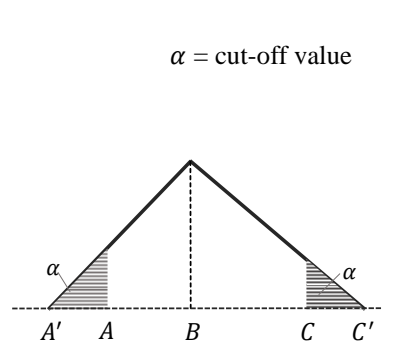

(i)

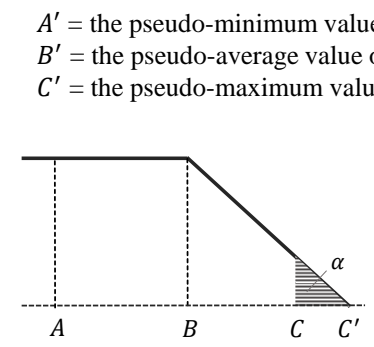

(ii)

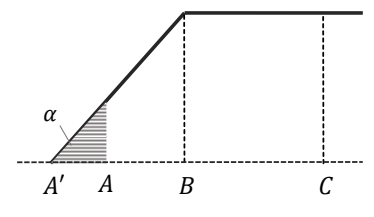

(iii)

Figure 5. The Cut-Off Parameter and the Pseudo-Distribution Form of the (i) Average-, (ii) Minimum-, and (iii) Maximum-Type.

The Penalty Factor PF is acting to counter cut-off parameter because PF works for variables fall out of their distribution intervals. The procedure is to honour the distribution classification of average-, minimum-, and maximum-type. Figure 6 delineates the geometrical consideration of the PF procedure.

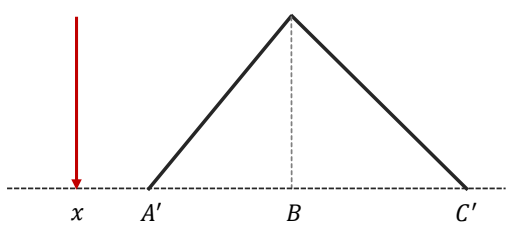

(i)

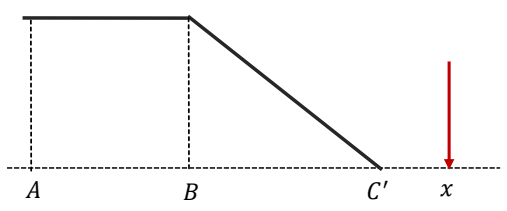

(iii)

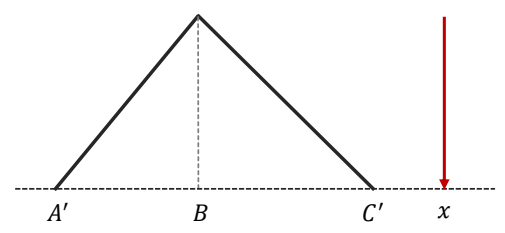

(ii)

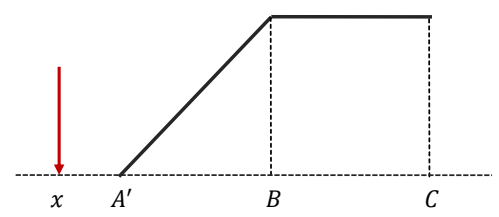

(iv)

Figure 6. Graphical Conception of the Penalty Factor Procedure for (i, ii) Average-Type, (iii) MinimumType, and (iv) Maximum-Type Properties.

After individual fitness scores have been confirmed, a weighting factor $w_{i}$ was implemented to each of the individual fitness scores $P_{i}$ in order to accommodate the relative importance of particular property in a specific EOR method. The more important a particular property in a specific EOR method, the higher the value of the weighting factor. A minimum value of zero and a maximum value of five were determined for the weighting factor value. Table A3 of Appendix summarizes the default value of the weighting factors. The total fitness score TFS for a particular EOR method comes up as presented by Equation 1.

$$
\operatorname{TFS}_{E O R_{(k)}}=\frac{\sum_{j=1}^{8} w_{j} P(x)_{j}}{\sum_{j=1}^{8} w_{j}}=\frac{w_{1} P(x)_{1}+w_{2} P(x)_{2}+\cdots+w_{8} P(x)_{8}}{w_{1}+w_{2}+\cdots+w_{8}}
$$

\subsubsection{Screening Algorithm for Distribution-Value Input}

Distribution-value input is a case in which the input properties of a given reservoir is in the form of continuous distribution, which characterization depends on the user-selected distribution: uniform, triangular, normal, and lognormal. The underlying principle for the distribution input is to find the points 
of intersection between two continuous distributions: screening criteria and input distribution. The individual fitness score was then determined by calculating intersection area of them using Simpson rule. The Newton-Raphson procedure is to obtain the intersection point(s) between the two distribution curves.

This feature is very useful for variables which are always present in a distribution such as porosity and permeability. The typical rock porosity is in lognormal distribution where it is always correlated with permeability in a unique trend named rock type (Hakiki and Wibowo, 2014).

\subsection{EOR Predictive Model}

After the most appropriate EOR method has appeared, the subsequent stage is to examine the performance of a particular EOR method in the reservoir of interest. This work deployes a predictive model scheme developed by the United States Department of Energy (U.S. DOE). A total of eight EOR predictive models were included in the study (U.S. DOE and the Ministry of Energy and Mines of the Republic of Venezuela 1986a, 1986b, 1986c, 1986d, 1986e, 1986f; U.S. DOE and Texaco EPTD 1992). The infill drilling model is available as a supplementary option. Table 3 summarises the available EOR predictive models in our study.

Table 3. EOR Predictive Models Incorporated in the Study.

\begin{tabular}{|c|c|}
\hline EOR Predictive Model & Modeled Mechanisms \\
\hline $\mathrm{CO}_{2}$ Miscible Flood Predictive Model (CO2PM) & Miscible $\mathrm{CO}_{2}$ \\
\hline $\mathrm{CO}_{2}$-Prophet & $\begin{array}{l}\text { Miscible } \mathrm{CO}_{2}-\mathrm{WAG} \\
\text { Immiscible } \mathrm{CO}_{2}\end{array}$ \\
\hline Polymer Predictive Model (PFPM) - Polymer Module & Polymer Flood \\
\hline $\begin{array}{l}\text { Polymer Predictive Model (PFPM) - Waterflood } \\
\text { Module }\end{array}$ & Water Flood \\
\hline Chemical Flood Predictive Model (CFPM) & $\begin{array}{l}\text { Micellar-Polymer (Surfactant-Polymer) Flood } \\
\text { Caustic (Alkaline) Flood } \\
\text { Caustic-Polymer (Alkaline-Polymer) Flood }\end{array}$ \\
\hline Steam Flood Predictive Model (SFPM) & Steam Flood \\
\hline In-Situ Combustion Predictive Model (ICPM) & In-Situ Combustion \\
\hline Infill Drilling Predictive Model (IDPM) & Infill Drilling \\
\hline
\end{tabular}

Additional computer codes were generated to link the predictive modules with other modules in the study (Hartono et al. 2017). Several objective functions which describe EOR performance are available as options to provide an aggregate information to engineers.

\subsection{EOR Economic Analysis}

Economics plays a fundamental role in oil and gas industry. EOR is an expensive project and final decision to implement EOR in a certain field often relies more on economics rather than technical aspect (Taber et al. 1997b). Profit will always be the primary consideration when deciding an EOR implementation. The economic module is linked to the other modules, thus enabling engineers to perform an economical assessment with ease.

The module adapts the Cost Recovery Production Sharing Contract (PSC) system of Indonesia. The toolkit is suitable for assessing an economic aspect of EOR opportunity in Indonesia. The Net Present Value (NPV), Rate of Return (ROR), and Pay-Out Time (POT) are the three available objective variables in the economic module. Spider chart option offers a way to understand the significance of oil price, investment, 
and operational costs to the economic attractiveness of a candidate EOR project. EOR price is the most fundamental factor which determines the decision of EOR project. This results are in agreement with the previous study (Taber et al. 1997b).

\subsection{EOR Risk Analysis}

The risk analysis module is connected to the previous predictive and economic modules, thus allowing engineers to choose technical or financial parameter as the objective variable. Monte Carlo simulation is employed to perform the risk and uncertainty analysis. The procedure is started by specifying the search space of the problem at hand by inserting the minimum, maximum, and average values of particular controllable reservoir properties. The algorithms would select a specific value for every reservoir properties considered by random manner. The respective predictive or economic modules will be run automatically depends on the respective objective variable chosen. The procedure is repeated $n$ times, as many as a number of random simulation to be performed. Important features of the risk and uncertainty would be identified as P10, P50, and P90 on a cumulative frequency graph.

\subsection{EOR Optimization Evaluation}

Optimization assessment is the final stage of the EOR preliminary assessment of the present study. The primary challenge in performing optimisation evaluation in this study is that the true objective function which relates the response variable and the independent variables of a particular EOR process is unknown and perhaps involving a complicated mathematical formulation. Therefore, the exact optimum solution of EOR process is not possible to be found. Hence, the only solution that is possible to be gained is an approximate solution through numerical algorithms. This approximate solution is also known as the nearoptimum solution. In other words, although the most optimum solution may exist, it is hard to find a better solution than the near-optimum solution.

We applied the stochastic methods to find the near-optimum solution of EOR optimisation. Stochastic methods are procedures to find the near-optimum solution of a problem based on random number generation (Ambia, 2012). Certain rules are applied to the random numbers so that they would act as "searching agents" in the defined search space with the objective of finding a near-optimum solution. The procedures did not require the knowledge of the mathematical formulation of the problem (Ambia, 2012), hence they are suitable to be implemented in our EOR optimisation endeavour. Three stochastic procedures of Genetic Algorithm (GA), Particle Swarm Optimization (PSO), and Evolutionary Strategy (ES) were implemented in this study. The module was connected to the predictive and economic modules and automatically search the near-optimum solution through the use of one of these previous modules to generate the solution candidates.

\section{Results and Discussion}

\subsection{EOR Screening Evaluations}

Implemented algorithm into an in-house software will be tested for some selected field/laboratory cases in Indonesia. There will be three cases of EOR Screening to evaluate and discuss: (1) success projects and recommended by the algorithm, (2) success projects but slightly contradict the algorithm's results, (3) fail projects and not either supported by the algorithm. We could not find any case of a fail project in which the algorithm expects a successful execution. Table 4 recaps the screening results for selected fields in Indonesia. 
Table 4. EOR Screening of Selected Fields in Indonesia.

\begin{tabular}{|c|c|c|c|c|c|c|c|c|c|}
\hline \multirow{2}{*}{$\begin{array}{l}\text { Reservoir/Fluid } \\
\text { Properties }\end{array}$} & \multicolumn{9}{|c|}{ FIELD } \\
\hline & Tempino & Kenali Asam & Duri & Duri & Minas & Minas & Ledok & Klamono & Handil \\
\hline Oil Gravity [ $\left.{ }^{\circ} \mathrm{API}\right]$ & 43.2 & 42.2 & 22.7 & 22.7 & 36 & 36 & 43 & 17.5 & 34 \\
\hline Oil viscosity [cP] & 0.9 & 0.9 & 100 & 100 & 3.5 & 3.5 & 7 & 68 & 0.6 \\
\hline Porosity [\%] & 27.1 & 23.7 & 36 & 36 & 32.3 & 32.3 & 34.1 & 23.4 & 25.0 \\
\hline Oil Saturation [\%] & 23 & 11 & 10 & 10 & 20 & 20 & 50 & 50 & 20 \\
\hline Depth [ft] & 1270 & 1753 & 1680 & 1680 & 2342 & 2342 & 610 & 929 & 6070 \\
\hline Temperature $\left[{ }^{\circ} \mathrm{F}\right]$ & 154.4 & 154.4 & 100.4 & 100.4 & 199.4 & 199.4 & 84.2 & 125.6 & 258.0 \\
\hline Permeability [mD] & 239 & 170 & 500 & 500 & $343-1500$ & $343-1500$ & 140 & 400 & $10-2000$ \\
\hline Formation Type & Sandstone & Sandstone & Sandstone & Sandstone & Sandstone & Sandstone & Sandstone & Carbonate & Sandstone \\
\hline Application Remarks & $\begin{array}{l}\text { Success in } \\
\text { Laboratory } \\
\text { Scale }\end{array}$ & $\begin{array}{l}\text { Success in } \\
\text { Laboratory } \\
\text { Scale }\end{array}$ & $\begin{array}{l}\text { Success in Full } \\
\text { Field Scale }\end{array}$ & $\begin{array}{c}\text { Failure in Field } \\
\text { Trial }\end{array}$ & $\begin{array}{l}\text { Success in } \\
\text { Field Trial }\end{array}$ & $\begin{array}{c}\text { Failure in Field } \\
\text { Trial }\end{array}$ & $\begin{array}{l}\text { Success in } \\
\text { Field Trial }\end{array}$ & $\begin{array}{l}\text { Success in } \\
\text { Field Trial }\end{array}$ & $\begin{array}{l}\text { Success in Full } \\
\text { Field Scale }\end{array}$ \\
\hline Type of Application & $\begin{array}{l}\text { Chemical } \\
\text { Injection } \\
\text { (Surfactant- } \\
\text { Polymer) }\end{array}$ & $\begin{array}{l}\text { Chemical } \\
\text { Injection } \\
\text { (Surfactant- } \\
\text { Polymer) }\end{array}$ & Steam Flood & $\begin{array}{l}\text { Chemical } \\
\text { Injection } \\
\text { (Alkaline) }\end{array}$ & $\begin{array}{l}\text { Chemical } \\
\text { Injection } \\
\text { (Surfactant- } \\
\text { Polymer) }\end{array}$ & Steam Flood & MEOR & $\begin{array}{l}\text { Thermal } \\
\text { Induction }\end{array}$ & $\begin{array}{l}\text { Lean Gas } \\
\text { Injection }\end{array}$ \\
\hline Executing Year & 2015 & 2015 & 1983-2014 & 1975 & 2000 & 1998 & 1999 & 2014 & 1995-1999 \\
\hline \multicolumn{10}{|c|}{ EOR SCREENING RESULTS } \\
\hline Rank 1 & Miscible $\mathrm{CO}_{2}$ & Miscible $\mathrm{CO}_{2}$ & Steam Flood & Steam Flood & $\begin{array}{l}\text { Immiscible } \\
\text { Nitrogen }\end{array}$ & $\begin{array}{l}\text { Immiscible } \\
\text { Nitrogen }\end{array}$ & $\begin{array}{l}\text { Surfactant + } \\
\text { Polymer }\end{array}$ & $\begin{array}{c}\text { Immiscible } \\
\mathrm{CO}_{2}\end{array}$ & $\begin{array}{l}\text { Immiscible } \\
\text { Nitrogen }\end{array}$ \\
\hline Rank 2 & $\begin{array}{l}\text { Alkaline- } \\
\text { Surfactant- } \\
\text { Polymer }\end{array}$ & $\begin{array}{l}\text { Immiscible } \\
\text { Nitrogen }\end{array}$ & $\begin{array}{c}\text { Immiscible } \\
\mathrm{CO}_{2}\end{array}$ & $\begin{array}{c}\text { Immiscible } \\
\mathrm{CO}_{2}\end{array}$ & Miscible $\mathrm{CO}_{2}$ & Miscible $\mathrm{CO}_{2}$ & $\begin{array}{l}\text { Alkaline- } \\
\text { Surfactant- } \\
\text { Polymer }\end{array}$ & Steam Flood & Miscible $\mathrm{CO}_{2}$ \\
\hline Rank 3 & Polymer & $\begin{array}{c}\text { Miscible } \\
\text { Hydrocarbon }\end{array}$ & Hot Water & Hot Water & $\begin{array}{l}\text { Alkaline- } \\
\text { Surfactant- } \\
\text { Polymer }\end{array}$ & $\begin{array}{l}\text { Alkaline- } \\
\text { Surfactant- } \\
\text { Polymer }\end{array}$ & Polymer & Polymer & $\begin{array}{c}\text { Miscible } \\
\text { Hydrocarbon }\end{array}$ \\
\hline Rank 4 & $\begin{array}{l}\text { Immiscible } \\
\text { Nitrogen }\end{array}$ & Steam Flood & $\begin{array}{c}\text { In-Situ } \\
\text { Combustion }\end{array}$ & $\begin{array}{c}\text { In-Situ } \\
\text { Combustion }\end{array}$ & $\begin{array}{c}\text { Immiscible } \\
\text { Hydrocarbon } \\
\text { + WAG }\end{array}$ & $\begin{array}{c}\text { Immiscible } \\
\text { Hydrocarbon + } \\
\text { WAG }\end{array}$ & Miscible $\mathrm{CO}_{2}$ & $\begin{array}{l}\text { Hot Water } \\
\text { Flood }\end{array}$ & $\begin{array}{l}\text { Immiscible } \\
\text { Hydrocarbon } \\
\text { + WAG }\end{array}$ \\
\hline Rank 5 & $\begin{array}{c}\text { Miscible } \\
\text { Hydrocarbon }\end{array}$ & Polymer & $\begin{array}{l}\text { Immiscible } \\
\text { Nitrogen }\end{array}$ & $\begin{array}{l}\text { Immiscible } \\
\text { Nitrogen }\end{array}$ & $\begin{array}{c}\text { Miscible } \\
\text { Hydrocarbon }\end{array}$ & $\begin{array}{c}\text { Miscible } \\
\text { Hydrocarbon }\end{array}$ & $\begin{array}{l}\text { Immiscible } \\
\text { Nitrogen }\end{array}$ & $\begin{array}{l}\text { Surfactant + } \\
\text { Polymer }\end{array}$ & $\begin{array}{c}\text { Immiscible } \\
\mathrm{CO}_{2}\end{array}$ \\
\hline Rank 6 & Steam Flood & $\begin{array}{c}\text { Immiscible } \\
\text { Hydrocarbon + } \\
\text { WAG }\end{array}$ & $\begin{array}{c}\text { Immiscible } \\
\text { Hydrocarbon + } \\
\text { WAG }\end{array}$ & $\begin{array}{c}\text { Immiscible } \\
\text { Hydrocarbon } \\
\text { + WAG }\end{array}$ & Polymer & Polymer & Steam Flood & $\begin{array}{c}\text { In Situ } \\
\text { Combustion }\end{array}$ & Polymer \\
\hline Rank 7 & $\begin{array}{c}\text { Immiscible } \\
\text { Hydrocarbon + } \\
\text { WAS }\end{array}$ & Hot Water & Polymer & Polymer & $\begin{array}{c}\text { Immiscible } \\
\mathrm{CO} 2\end{array}$ & $\begin{array}{c}\text { Immiscible } \\
\mathrm{CO} 2\end{array}$ & $\begin{array}{l}\text { Hot Water } \\
\text { Flood }\end{array}$ & $\begin{array}{l}\text { Immiscible } \\
\text { Nitrogen }\end{array}$ & $\begin{array}{l}\text { Miscible } \\
\text { WAG }\end{array}$ \\
\hline Rank 8 & Hot Water & $\begin{array}{c}\text { In-Situ } \\
\text { Combustion }\end{array}$ & $\begin{array}{l}\text { Alkaline- } \\
\text { Surfactant- } \\
\text { Polymer }\end{array}$ & $\begin{array}{l}\text { Alkaline- } \\
\text { Surfactant- } \\
\text { Polymer }\end{array}$ & Steam Flood & Steam Flood & $\begin{array}{c}\text { In Situ } \\
\text { Combustion }\end{array}$ & $\begin{array}{l}\text { Immiscible } \\
\text { Hydrocarbon } \\
\text { + WAG }\end{array}$ & $\begin{array}{l}\text { Alkaline- } \\
\text { Surfactant- } \\
\text { Polymer }\end{array}$ \\
\hline Rank 9 & $\begin{array}{c}\text { In-Situ } \\
\text { Combustion }\end{array}$ & $\begin{array}{l}\text { Alkaline- } \\
\text { Surfactant- } \\
\text { Polymer }\end{array}$ & $\begin{array}{c}\text { Surfactant + } \\
\text { Polymer }\end{array}$ & $\begin{array}{c}\text { Surfactant + } \\
\text { Polymer }\end{array}$ & $\begin{array}{l}\text { Hot Water } \\
\text { Flood }\end{array}$ & $\begin{array}{l}\text { Hot Water } \\
\text { Flood }\end{array}$ & $\begin{array}{c}\text { Immiscible } \\
\text { Hydrocarbon + } \\
\text { WAG }\end{array}$ & Microbial & Steam Flood \\
\hline Rank 10 & Immiscible $\mathrm{CO}_{2}$ & Immiscible $\mathrm{CO}_{2}$ & Microbial & Microbial & $\begin{array}{c}\text { In Situ } \\
\text { Combustion }\end{array}$ & $\begin{array}{c}\text { In Situ } \\
\text { Combustion }\end{array}$ & Immiscible $\mathrm{CO} 2$ & $\begin{array}{l}\text { Alkaline- } \\
\text { Surfactant- } \\
\text { Polymer }\end{array}$ & $\begin{array}{l}\text { Hot Water } \\
\text { Flood }\end{array}$ \\
\hline Rank 11 & Miscible WAG & Miscible WAG & Miscible $\mathrm{CO}_{2}$ & Miscible $\mathrm{CO}_{2}$ & $\begin{array}{c}\text { Surfactant }+ \\
\text { Polymer }\end{array}$ & $\begin{array}{c}\text { Surfactant + } \\
\text { Polymer }\end{array}$ & $\begin{array}{c}\text { Miscible } \\
\text { Hydrocarbon }\end{array}$ & Miscible $\mathrm{CO}_{2}$ & $\begin{array}{c}\text { In Situ } \\
\text { Combustion }\end{array}$ \\
\hline Rank 12 & $\begin{array}{l}\text { Surfactant + } \\
\text { Polymer }\end{array}$ & $\begin{array}{l}\text { Miscible } \\
\text { Nitrogen }\end{array}$ & $\begin{array}{l}\text { Miscible } \\
\text { Hydrocarbon }\end{array}$ & $\begin{array}{c}\text { Miscible } \\
\text { Hydrocarbon }\end{array}$ & Microbial & Microbial & Microbial & $\begin{array}{c}\text { Miscible } \\
\text { Hydrocarbon }\end{array}$ & $\begin{array}{l}\text { Miscible } \\
\text { Nitrogen }\end{array}$ \\
\hline Rank 13 & $\begin{array}{l}\text { Miscible } \\
\text { Nitrogen }\end{array}$ & $\begin{array}{c}\text { Surfactant + } \\
\text { Polymer }\end{array}$ & $\begin{array}{l}\text { Immiscible } \\
\text { Hydrocarbon }\end{array}$ & $\begin{array}{l}\text { Immiscible } \\
\text { Hydrocarbon }\end{array}$ & $\begin{array}{l}\text { Immiscible } \\
\text { Hydrocarbon }\end{array}$ & $\begin{array}{l}\text { Immiscible } \\
\text { Hydrocarbon }\end{array}$ & $\begin{array}{l}\text { Immiscible } \\
\text { Hydrocarbon }\end{array}$ & $\begin{array}{l}\text { Immiscible } \\
\text { Hydrocarbon }\end{array}$ & $\begin{array}{c}\text { Surfactant + } \\
\text { Polymer }\end{array}$ \\
\hline Rank 14 & Microbial & $\begin{array}{l}\text { Immiscible } \\
\text { Hydrocarbon }\end{array}$ & Miscible WAG & Miscible WAG & Miscible WAG & Miscible WAG & Miscible WAG & Miscible WAG & Microbial \\
\hline Rank 15 & $\begin{array}{l}\text { Immiscible } \\
\text { Hydrocarbon }\end{array}$ & Microbial & $\begin{array}{l}\text { Miscible } \\
\text { Nitrogen }\end{array}$ & $\begin{array}{l}\text { Miscible } \\
\text { Nitrogen }\end{array}$ & $\begin{array}{l}\text { Miscible } \\
\text { Nitrogen }\end{array}$ & $\begin{array}{l}\text { Miscible } \\
\text { Nitrogen }\end{array}$ & $\begin{array}{l}\text { Miscible } \\
\text { Nitrogen }\end{array}$ & $\begin{array}{l}\text { Miscible } \\
\text { Nitrogen }\end{array}$ & $\begin{array}{l}\text { Immiscible } \\
\text { Hydrocarbon }\end{array}$ \\
\hline
\end{tabular}

Compiled from: Hakiki et al. (2015); Subiyantoro, G. (2010); Gael et al. (1994); Hendih et al. (2002); Erlich et al (1997); Abdurrahman et al. (2016); Bou-Mikael et al. (2000); Gunawan et al (2001); Hakiki, F. (2014b); Yusuf et al. (1999); Hakiki et al. (2017); Indonesia, Oil and Gas Fields Atlas of Vol.: 3 (1990), 2 (1991); 4 (1989); 6 (1988); 5 (1991). 


\section{Case 1}

This case deals with successful projects and also recommended by the algorithm. These fields are highlighted with green in Table 4. This algorithm test confirms that the big three positions are possible to reach successful implementations: laboratory scale (Tempino), field trial (Minas and Klamono), and full field (Duri and Handil).

Tempino is still restricted to laboratory coreflooding where various slugs of surfactant and polymer flood performed (Hakiki et al. 2015) while Minas Surfactant Project has given good results (Bou-Mikael et al. 2000). The first and second position turns out to be a chemical injection. The point of chemical EOR is to reduce interfacial tension $\sigma$ contributed by surfactant, increase sweep efficiency by polymer and alter wettability by introducing alkaline.

Chemical-based EOR is suited best with minimum depth and temperature because temperature (higher as goes deeper) is crucial to the thermal stability of chemical-agent. Some polymers may be broken (turned to be monomer) as it reaches a limiting temperature. The widely-used polymer in the petroleum industry is polyacrylamide (PAM) or hydrolysed polyacrylamide (HPAM) with the maximum working temperature around $100{ }^{\circ} \mathrm{C}\left(\sim 212^{\circ} \mathrm{F}\right)$ (Abidin et al. 2012). Some modified or crosslinked PAM or HPAM could work with higher temperature (Abidin et al. 2012; Hakiki, F. 2014a). Therefore, "minimum-type" distribution should address temperature and depth variable. It is suitable for chemical EOR works for light oil and low viscosity because the chemical agent could work as a different phase fluid than oil that is water-phase in which piston-like displacement is desired. Piston like displacement (stable flow) occurs once invadingfluid viscosity $\mu_{i n v}$ is higher than displaced's one $\mu_{\text {disp }}$ (Mobility ratio $M=\mu_{i n v} / \mu_{d i s p}>1$ ) and capillary number $N_{C a}\left(=v_{i n v} \mu_{i n v} / \sigma\right)$ is also high. (Lenormand et al. 1988).

Heating-based EOR appears in Table 4 as the first suggestion for Duri Field and second suggestion for Klamono as they hold very high oil viscosity. Duri has confirmed to be one of a successful steamflood project in the world while Klamono Field Trial was only still 2 days well heating. Heating-based EOR is practical to reduce viscosity so that the oil will easily flow through porous media and pipe (Hakiki et al. 2017). Some extent effects of heating might alter wettability and reduce oil-water interfacial tension. A viscous oil tends to have higher density (lower API) since heavy components are associated. Heating EOR, thus, outlines with bigger weight and "maximum-type" distribution for viscosity and "minimum-type" for API gravity.

Handil is the least viscous oil in Table 4 and considerably light oil. This condition may call water-based EOR (ASP flood, Polymer flood, Hot Water) and gas-based EOR since it is light and lean oil. Rank 1 to 8 reveals both water and gas-based EOR. It does, however, possess very high temperature $126{ }^{\circ} \mathrm{C}(\sim 258$ ${ }^{\circ} \mathrm{F}$ ) hence chemical agent may not withstand this heat. Gas-based is, hence, a perfect alternative for this hot reservoir. This research advises a gas injection from Rank 1 to 5. Handil lean gas injection has been promising for three years injection since November 1995 (Gunawan 2001). A lean hydrocarbon gas in light oil reservoir is basically an immiscible process. The gravity drainage of oil handles the primary role, which, in Handil, had already experienced a waterflood treatment.

The residual oil is preserved in tighter pores by interfacial forces in preference to the gas (Sakthikumar et al. 1992). Oil trapped by surface capillary forces is expected being transformed into thin films between gas-water interface when the lean gas is introduced. Gravity or viscous force will then drive the oil films to get produced (Kantzas et al. 1988, Sakthikumar et al. 1992, Gunawan 2001). The existence of low permeability layer in controlled drainage case will allow stabilizing the gas flow and the displacing-gas rate are minute compared to the initial rates in free drainage case and the oil bank is possible to form. Higher initial rates in free drainage case permit oil area is bypassed by the gas front (Kantzas et al. 1988). 


\section{Case 2}

Case 2 elaborates the successful projects, but slightly contradict the algorithm's results. The fields arise with yellow-highlighted cell in Table 4. The algorithm has a matching case where the lists are out of the big three position. Kenali Asam and Ledok are the samples which stay at $5^{\text {th }}$ and $12^{\text {th }}$ rank for chemical EOR and MEOR, consecutively.

Kenali Asam is almost similar to Tempino but the significant differences are the residual oil and depth as their input. Residual oil is, in fact, vary depends on the area being studied. Kenali Asam results was still on the laboratory scale for various surfactant-polymer slug size flooding (Hakiki et al. 2015).

MEOR could be considered the last option of EOR because it may take higher cost and longer laboratory study. The study involves the suitability of oil and brine to bacteria and nutrient as well. Bacteria could be cultivated from indigenous bacteria or an external one. The MEOR hardest part is to make sure the microorganisms is evenly distributed throughout the reservoir (Yen 1989), then ensure the bacteria withstand with high pressure, high temperature, competition with other type bacteria, and predator-prey behaviour with their bioproducts (Hakiki 2014b, Putra et al. 2017). The use of microbes is to consume and/or transform the high fraction hydrocarbon components to be lower fraction hence the oil gets less dense and less viscous (Purwasena et al. 2010, 2014). The bioproducts of bacteria: gas, organic acids, solvents, polymer, and/or surfactants are acting like chemical-EOR agents to increase sweep efficiency, alter wettability, and reduce interface energy (Halim 2015, Halim et al. 2015).

Ledok is the first MEOR project in Indonesia whose oil rate had increased from 8.18 BOPD in 15 July 1999 after injection on 8 July 1999 (Yusuf et al. 1999). Table 4 suggests that Ledok could be treated with chemical-based EOR from $1^{\text {st }}$ to $3^{\text {rd }}$ rank. The successful of MEOR implementation could be justified since the MEOR mechanism is similar to chemical-based EOR.

\section{Case 3}

The last case is about to discuss fail projects and not either supported by the algorithm. Red-highlighted cells indicate this group. Duri and Minas field has already been discussed in the Case 1. This lesson learnt is to unveil that our algorithm is robust to predict the EOR method suitability. It is not only statistically speaking but also EOR mechanism-based explanations could in-depth cover these failures.

Case 1 undergoes that the best options to execute in the laboratory, field trial, full field lies on the three best offers. Case 2 opens a thought that similar EOR mechanism may be in the different form of EOR suggestion. MEOR is more likely related to Chemical-EOR. It needs more extreme real field data to elaborate the case. The slightly-missed ranking may be due to the limited database, in which dynamic update of the database is required.

\subsection{Advance Studies}

\section{Revisiting Minas Field}

We selected Minas Field as the first case to be evaluated by our EOR preliminary assessment toolkit with detailed properties served in Table 5. Minas is a giant oil field located in the central Sumatra basin of Indonesia. The field has been identified as one of the largest oil fields in Southeast Asia with an estimated original oil in place of 9 billion barrels (Bou-Mikael et al. 2000). Until the year of 2000, Minas has produced up to 4.2 billion barrels of oil (Bou-Mikael et al. 2000). It was also estimated that around 4.5 billion barrels of remaining oil was available in Minas for the target of EOR technology (Bou-Mikael et al. 2000). Several EOR field trials have been attempted at the particular field since the year of 2000. It has 
been identified that implementation of chemical flooding, especially the surfactant-polymer (SP) flooding, produced promising oil recovery (Bou-Mikael et al. 2000; Masduki et al. 2010).

Table 5. Input for Predictive and Optimisation Module: Case Study of Minas Field.

\begin{tabular}{|ccc|}
\hline Properties & Value & Unit \\
\hline Pattern Area & 4.3 & [acres] \\
Current Reservoir Pressure & 450 & [psi] \\
Oil FVF & 1.08 & [bbl/STB] \\
Water FVF & 1.003 & [bbl/STB] \\
Water Salinity & 2465 & [ppm] \\
Remaining Oil in Place for 1 Pattern & 0.2795 & [MMSTB] \\
Surfactant Concentration (of PV) & 0.02 & [ ] \\
Surfactant Slug Size (of PV) & 0.25 & [ ] \\
Polymer Slug Size & 0.5 & [] \\
Pattern Injection Rate & 950 & {$[\mathrm{bbl} / \mathrm{day}]$} \\
\hline
\end{tabular}

Table 6 expresses the summary of reservoir performace evaluation of Minas field. Early reservoir performance assessment based on the true flooding design provided cumulative oil production of 19.5 MSTB for total injection period of 160 days. Meanwhile, the record of true surfactant-polymer field trial at Minas showed a higher cumulative oil production of 62.44 MSTB in a far shorter injection period of 7.4 days. The discrepancy is due to to the fact that the U.S. predictive models were conservative models, which means that their predictive outcomes would tend to be lower than the real situation.

Table 6. Predictive Model Outcomes for Minas Field and Its Comparison to the True Results.

\begin{tabular}{|cc|}
\hline \multicolumn{2}{|c|}{ Predictive Model Result } \\
\hline $\begin{array}{c}\text { Time Period } \\
\text { [Days] }\end{array}$ & $\begin{array}{c}\text { Cumulative Oil } \\
\text { Produced [MSTB] }\end{array}$ \\
\hline 60 & 0 \\
90 & 5.8 \\
120 & 14.5 \\
160 & 19.5 \\
\hline
\end{tabular}

\begin{tabular}{|cc|}
\hline \multicolumn{2}{|c|}{ Minas Field Trial True Result } \\
\hline $\begin{array}{c}\text { Time Period } \\
\text { [Days] }\end{array}$ & $\begin{array}{c}\text { Cumulative Oil } \\
\text { Produced [MSTB] }\end{array}$ \\
\hline 0.51 & 4.91 \\
3.52 & 33.71 \\
6.16 & 52.78 \\
7.42 & 62.44 \\
\hline
\end{tabular}

Based on the premise that the target oil (remaining oil in place) of the pattern is approximately 280 MSTB, the cumulative oil production of the predictive model and the true field trial represented $7 \%$ and $22.2 \%$ recovery factors (RF), respectively. The discrepancy could be minimised by performing optimisation study. Table 7 conveys the result from optimisation evaluation. Particle Swarm Optimization (PSO) procedure yielded the highest cumulative oil production than the other two schemes, hence it was chosen as the optimum design.

Table 7. Results from Optimization Module for Minas Field Assessments.

\begin{tabular}{|cc|}
\hline Stochastic Method & Cumulative Oil Production [MSTB] \\
\hline Genetic Algorithm & 27.7 \\
Particle Swarm Optimization & 27.9 \\
Evolutionary Strategy & 27.8 \\
\hline Optimum Scenario: Particle Swarm Optimization \\
\hline Controllable Factors & Level of Controllable Factors \\
\hline Surfactant Concentration [ ] & 0.014 \\
Injection Rate [bbl/day] & 745 \\
Surfactant Slug Size (of PV) [ ] & 0.4 \\
Polymer Slug Size (of PV) [ ] & 0.5 \\
\hline
\end{tabular}


Table 8 demonstrates that the optimisation study surfactant-polymer flood ameliorates cumulation oil production up to 27.9 MSTB from the initial value of 19.5 MSTB. This is equivalent to 10\% RF. Although this value is still below the true value of Minas trial flood, the discrepancy between the predicted and true value was successfully reduced. This confirms the objective of optimisation evaluation.

Table 8. Optimization Study of Cumulative Oil Production.

\begin{tabular}{|cc|}
\hline \multicolumn{2}{|c|}{ Predictive Model Result: Optimum Scenario } \\
\hline Time Period [Days] & Cumulative Oil Produced [MSTB] \\
\hline 91.25 & 0 \\
182.5 & 16.5 \\
273.75 & 25.7 \\
299.3 & 27.9 \\
\hline
\end{tabular}

Economic assessment of the project revealed that oil price and investment are two parameters which significantly affect the economic feasibility. Risk assessment result is summarised in Table 9, in which the P50 and P90 of the project were displayed. Figure A1 to A4 of the appendix expose the screenshots of the assessments.

Table 9. Outcomes from Risk Analysis of Minas Field.

\begin{tabular}{|cccc|}
\hline Risk Parameters & $\begin{array}{c}\text { Cumulative Oil Production } \\
\text { [MSTB] }\end{array}$ & Variables & Values \\
\hline P50 & 15.79 & Polymer Slug Size (of PV) [ ] & 0.262 \\
& & Pattern Injection Rate [bbl/day] & 287 \\
& Surfactant Concentration [ ] & 0.018 \\
& Surfactant Slug Size [ ] & 0.235 \\
\hline P90 & Polymer Slug Size (of PV) [ ] & 0.325 \\
& 21.04 & Pattern Injection Rate [bbl/day] & 630 \\
& & Surfactant Concentration [ ] & 0.025 \\
& Surfactant Slug Size [ ] & 0.289 \\
\hline
\end{tabular}

\section{Revisiting Duri Field}

Duri field is the second largest oil field in Indonesia in terms of the original oil in place. It is also the largest full-field steam flood project in the world (Gael et al. 1994, 1995). The field is located in Riau Province of Central Sumatera approximately $120 \mathrm{~km}$ northwest from Pekanbaru (Gael et al. 1994). It is intriguing to investigate this field through our toolkit and see the obtained results.

It is interesting to mention that the other thermal methods were listed in the top four of the rank. Reservoir performance prediction study was performed only on the Pertama and Kedua sands of the Duri field. The two sands have the largest contribution to the oil production of the field. It was estimated that the Pertama and Kedua field contains up to 4.1 billion barrels of original oil in place. With a total developed area of 15,100 acres, each flooding pattern contributed to 15.5 acres. The predictive model yielded approximately $6.8 \%$ of recovery factor from the steam flooding process. This value is in close agreement with the true reported recovery factor of $7.4 \%$. Economic analysis showed favourable outcome, although the economic attractiveness of the project would depend heavily on oil price and injection cost. Since steam injection rate was the only controllable factor in the study, optimisation evaluation could not be performed because the module would require minimum two controllable factors to define the search space. 


\section{Concluding Remarks}

The algorithm has a robust chance to assist engineer(s) seeing EOR methods possibility from limited reservoirs properties: oil gravity, oil viscosity, porosity, residual oil saturation, depth, temperature, permeability, and rock type.

The EOR screening developed from combining statistical and physical meaning (introduced through weight parameter $w_{i}$ ) has confirmed intense results with respect to the previous projects in Indonesia.

The integrated algorithm links EOR screening, predictive model, economic analysis, risk analysis, and optimisation evaluation, which is a strong consideration prior to applying at least laboratory study; which can later be extended to a pilot project.

\section{Acknowledgements and Notes}

The financial supports from Pertamina Upstream Technology Center (UTC) is appreciated. Help from Mr. Dede Alam Setiadi for the code development is highly acknowledged. Authors would also thank all former research assistants in this project. This research was carried out while A.D. Hartono and F. Hakiki were still at Institut Teknologi Bandung, Indonesia. All tested data is from published works and no confidentiality issues.

\section{References}

1. Abdurrahman, M., Bae, W. S., Novriansyah, A. and Khalid, I. 2016. Enhanced Oil Recovery (EOR) Challenges and Its Future in Indonesia. Proceeding of the IRES $28^{\text {th }}$ International Conference, Jakarta, Indonesia, 06 February 2016.

2. Abidin, A.Z., Puspasari, T., Nugroho, W. 2012. Polymers for Enhanced Oil Recovery Technology. Procedia Chemistry 4, 11-16. doi: 10.1016/j.proche.2012.06.002.

3. Abu El Ela, M., Sayyouh, H. and El Tayeb, E. S. 2014. An Integrated Approach for the Application of the Enhanced Oil Recovery Projects. Journal of Petroleum Science Research (JPSR), Vol. 3 (2014), Issue 4.

4. Al Adasani, A. and Bai, B. 2010. Recent Developments and Updated Screening Criteria of Enhanced Oil Recovery Techniques. SPE-130726-MS. Presented at the 2010 International Oil and Gas Conference and Exhibition, Beijing, China, 8 - 10 June 2010.

5. Al Adasani, A. and Bai, B. 2011. Analysis of EOR Projects and Updated Screening Criteria. Journal of Petroleum Science and Engineering, Vol. 79 (2011), pp. 10-24. doi: 10.1016/j.petrol.2011.07.005.

6. Al-Bahar, M., Merrill, R., Peake, W., Jumaa, M., and Oskui, R. 2004. Evaluation of IOR Potential within Kuwait. SPE 88716. Presented at the 11th Abu Dhabi International Petroleum Exhibition and Conference, Abu Dhabi, UAE, 10 - 13 October 2004.

7. Ambia, F. 2012. A Robust Optimization Tool Based on Stochastic Optimization Methods for Waterflooding Project. SPE-160907-STU. Presented at the 2012 SPE Annual Technical Conference and Exhibition, San Antonio, Texas, U.S.A., 8 - 10 October 2012.

8. Bou-Mikael, S., Asmadi, F., Marwoto, D. and Cease, C. 2000. Minas Surfactant Field Trial Tests Two Newly Designed Surfactants with High EOR Potential. SPE 64288. Presented at the 2000 SPE Asia Pacific Oil and Gas Conference and Exhibition, Brisbane, Australia, 16 - 18 October 2000. doi: 10.2118/64288-MS.

9. Dickson, Jasper L., Leahy-Dios, Alana, and Wylie, Philip L. 2010. Development of Improved Hydrocarbon Recovery Screening Methodologies. SPE 129768. Presented at the 2010 SPE Improved Oil Recovery Symposium, Tulsa, Oklahoma, USA, 24 - 28 April 2010.

10. Erlich, R., Greaser, G.R., Stevans, C.E., Asmadi, F., Ariyasa, O., Cease, C.C. 1997. Minas Light Oil Steamflood Evaluation. Paper SPE-37541-MS. International Thermal Operations and Heavy Oil Symposium, 10-12 February, Bakersfield, Californi

11. Gael, B. T., Putro, E. S., Masykur, A. and Lederhos, L. J. 1994. Reservoir Management in the Duri Steamflood. SPE 27764. Presented at the 1994 SPE/DOE Ninth Symposium on Improved Oil Recovery, Tulsa, Oklahoma, USA, 17 - 20 April 1994. 
12. Gael, B. T., Gross, S. J., and McNaboe, G. J. 1995. Development Planning and Reservoir Management in the Duri Steam Flood. SPE 29668. Presented at the 1995 Western Regional Meeting, Bakersfield, CA, USA, 8 10 March 1995.

13. Gunawan, S., Cale, D. 2001. Handil Field: Three Years of Lean-Gas Injection into Waterflooded Reservoirs. SPE Reservoir Evaluation \& Engineering 4(2), pp. 107-113.

14. Hakiki, F., Wibowo, A.T. 2014. Formulation of Rock Type Prediction in Cored Well Using Fuzzy Subtractive Clustering Algorithm. Paper IPA14-SE-118. Proceeding of the 38th Indonesian Petroleum Association Annual Convention \& Exhibition, May, Jakarta.

15. Hakiki, F. 2014a. Mathematical Model of Organically Cross-Linked Polymer Gelation Time to EOR Application. Bachelor Thesis. Institut Teknologi Bandung, Bandung, Indonesia.

16. Hakiki, F. 2014b. A Critical Review on Microbial Enhanced Oil Recovery Using Artificial Sandstone Core: Mathematical Model. Paper IPA14-SE-119. Proceeding of the 38th Indonesian Petroleum Association Annual Convention \& Exhibition, May, Jakarta.

17. Hakiki, F., Maharsi, D.A. and Marhaendrajana, T. 2015. Surfactant-Polymer Coreflood Simulation and Uncertainty Analysis Derived from Laboratory Study. J. Eng. Technol. Sci. 4(6), pp. 706-725. doi: 10.5614\%2Fj.eng.technol.sci.2015.47.6.9.

18. Hakiki, F., Aditya, A., Ulitha, D.T., Shidqi, M., Adi, W.S., Wibowo, K.H., Barus, M. 2017. Well and Inflow Performance Relationship for Heavy Oil Reservoir under Heating Treatment. Paper SPE-186187-MS. Presented at the 2017 SPE/IATMI Asia Pacific Oil \& Gas Conference and Exhibition, Bali, Indonesia. 17-19 October 2017.

19. Halim, A.Y. 2015. Application of Microorganisms for Enhanced Oil Recovery. PhD Thesis. Technical University of Denmark, Lyngby, Denmark.

20. Halim, A.Y., Pedersen, D.S., Nielsen, S.M., Lantz, A.E. 2015. Profiling of Indigenous Microbial Community Dynamics and Metabolic Activity During Enrichment in Molasses-Supplemented Crude Oil-Brine Mixtures for Improved Understanding of Microbial Enhanced Oil Recovery. Appl Biochem Biotechnol 176, pp. 10121028.

21. Hartono, A.D., Hakiki, F., Syihab, Z., Ambia, F., Efendi, M. 2017. Implementation of Algorithm to Assist EOR Preliminary Screening Evaluations. (manuscript in preparation)

22. Hendih, A.R., Imran, R., Williams, L.L. 2002. Investigation for Mature Minas Waterflood Optimization. Paper SPE-77924-MS. SPE Asia Pacific Oil and Gas Conference and Exhibition, 8-10 October, Melbourne, Australia.

23. Hon, V. Y., Kechut, N. I. and Razak, W. N. A. 2007. Enhanced Oil Recovery Potential of Heavy-Oil Fields in Africa. SPE-108513-MS. Presented at the 2007 International Oil Conference and Exhibition, Veracruz, Mexico, 27 - 30 June 2007. doi: 10.2118/108513-MS.

24. Indonesia, Oil and Gas Fields Atlas: Vol. 3: South Sumatra, 1990.

25. Indonesia, Oil and Gas Fields Atlas: Vol. 2: Central Sumatra, 1991.

26. Indonesia, Oil and Gas Fields Atlas: Vol. 4: Java, 1989.

27. Indonesia, Oil and Gas Fields Atlas: Vol. 6: Eastern Indonesia, 1988.

28. Indonesia, Oil and Gas Fields Atlas: Vol. 5: Kalimantan, 1991.

29. Kantzas, A., Chatzis, I., and Dullien, F.A. 1988. Enhanced Oil Recovery by Inert Gas Injection. SPE-17379MS.SPE Enhanced Oil Recovery Symposium, 16-21 April, Tulsa, Oklahoma.

30. Lenormand, R, touboul, E., \& Zarcone, C. 1988. Numerical Models and Experiments on Immiscible Displacements in Porous Media. J. of Fluid Mech, 189, pp. 165-187.

31. Masduki, A., Mario, C. C. and Syafwan, M. 2010. Application of Real-Time Surveillance System on Minas Surfactant Project. IPA10-E-081. Proceedings of the 2010 Indonesian Petroleum Association (IPA) $34^{\text {th }}$ Annual Convention and Exhibition, May 2010.

32. Purwasena, I.A., Sugai, Y., Sasaki, K. 2010. Estimation of the Potential of an Oil-Viscosity-Reducing Bacterium Petrotoga sp. Isolated from an Oil Field for MEOR. SPE-134961-MS. SPE Annual Technical Conference and Exhibition, 19-22 September, Florence, Italy.

33. Purwasena, I.A., Sugai, Y., Sasaki, K. 2014. Estimation of the potential of an anaerobic thermophilic oildegrading bacterium as a candidate for MEOR. J Petrol Explor Prod Technol 4, pp. 189-200.

34. Putra, W.D.K., Hakiki, F., Hesti, K. 2017. Modelling of Biosurfactant-producing Bacteria Growth and Interfacial Tension Response on Microbial Enhanced Oil Recovery (MEOR) Study. (manuscript in preparation) 
35. Sakthikumar, S., Madaoui, K., Thiebot, B., Bouvier, L. 1992. Experimental and numerical investigation into the feasibility of gas injection in waterflooded reservoirs. Paper IPA92-21.21. Proceeding of 21st Indonesian Petroleum Association Convention, Jakarta, Indonesia, October.

36. Subiyantoro, G. 2010. Post Steam Reservoir Characterization in Duri Steam Flood. Paper IPA10-G-109. Proceeding of the 34th IPA Annual Convention \& Exhibition, May, Jakarta.

37. Taber, J. J., Martin, F. D. and Seright, R. S. 1997a. EOR Screening Criteria Revisited - Part 1: Introduction to Screening Criteria and Enhanced Recovery Field Projects. SPE Reservoir Engineering Journal, Vol. 12 (1997), Issue 03, pp. $189-198$.

38. Taber, J. J., Martin, F. D. and Seright, R. S. 1997b. EOR Screening Criteria Revisited - Part 2: Applications and Impact of Oil Prices. SPE Reservoir Engineering Journal, Vol. 12 (1997), Issue 03, pp. 199-206.

39. The Department of Energy of the United States of America and the Ministry of Energy and Mines of the Republic of Venezuela. 1986a. Enhanced Oil Recovery Polymer Flood Predictive Model Report.

40. The Department of Energy of the United States of America and the Ministry of Energy and Mines of the Republic of Venezuela. 1986b. Enhanced Oil Recovery Chemical Flood Predictive Model Report.

41. The Department of Energy of the United States of America and the Ministry of Energy and Mines of the Republic of Venezuela. 1986c. Enhanced Oil Recovery $\mathrm{CO}_{2}$ Miscible Flood Predictive Model Report.

42. The Department of Energy of the United States of America and the Ministry of Energy and Mines of the Republic of Venezuela. 1986d. Enhanced Oil Recovery Steam Flood Predictive Model Report.

43. The Department of Energy of the United States of America and the Ministry of Energy and Mines of the Republic of Venezuela. 1986e. Enhanced Oil Recovery In-Situ Combustion Predictive Model Report.

44. The Department of Energy of the United States of America and the Ministry of Energy and Mines of the Republic of Venezuela. 1986f. Infill Drilling Predictive Model Report.

45. The Department of Energy of the United States of America and Texaco Exploration and Production Technology Department (EPTD). 1992. $\mathrm{CO}_{2}$-Prophet: Water and $\mathrm{CO}_{2}$ Flood Prediction Software.

46. Yen, T.F. 1989. Microbial Enhanced Oil Recovery: Principle and Practice. CRC Press.

47. Yusuf, A., Kadarwati, S., Nurkamelia, Sumaryana. 1999. Field Test of the Indigenous Microbes for oil Recovery, Ledok Field, Central Java. Paper SPE-57309-MS. SPE Asia Pacific Improved Oil Recovery Conference, 25-26 October, Kuala Lumpur, Malaysia. 


\section{Appendix}

Table A1. The Established Screening Criteria Database.

\begin{tabular}{|c|c|c|c|c|c|c|c|c|c|c|c|c|c|c|c|c|c|c|c|c|c|c|c|}
\hline \multirow{3}{*}{$\begin{array}{c}\text { EOR } \\
\text { Methods }\end{array}$} & \multicolumn{23}{|c|}{ Reservoir and Fluid Properties } \\
\hline & \multicolumn{3}{|c|}{$\begin{array}{c}\text { Oil API Gravity } \\
\left({ }^{\circ} \text { API }\right)\end{array}$} & \multicolumn{3}{|c|}{ Oil Viscosity (cP) } & \multicolumn{3}{|c|}{ Porosity (\%) } & \multicolumn{3}{|c|}{$\begin{array}{c}\text { Oil Saturation at } \\
\text { Initial Flooding } \\
(\%)\end{array}$} & \multicolumn{3}{|c|}{ Depth (ft) } & \multicolumn{3}{|c|}{ Temperature $\left({ }^{\circ} \mathbf{F}\right)$} & \multicolumn{3}{|c|}{ Permeability (mD) } & \multicolumn{2}{|c|}{$\begin{array}{l}\text { Formation } \\
\text { Type }\end{array}$} \\
\hline & Min & Avg. & $\operatorname{Max}$ & Min & Avg. & Max & Min & Avg. & Max & Min & Avg. & $\operatorname{Max}$ & Min & Avg. & $\operatorname{Max}$ & Min & Avg. & $\operatorname{Max}$ & Min & Avg. & $\operatorname{Max}$ & $\mathrm{S}^{*}$ & $\mathrm{C}^{* *}$ \\
\hline Miscible $\mathrm{CO}_{2}$ & 22 & 36 & 45 & 0.3 & 1.65 & 35 & 3 & 14.8 & 37 & 15 & 52.75 & 89 & 1500 & 6171.2 & 13365 & 82 & 136.3 & 250 & 1.5 & 201.1 & 4500 & 1 & 1 \\
\hline $\begin{array}{c}\text { Miscible } \\
\text { Hydrocarbon }\end{array}$ & 23 & 40 & 57 & 0.04 & 134.3 & 18000 & 4.25 & 14.5 & 45 & 30 & 76.5 & 98 & 4000 & 6191.8 & 15900 & 85 & 202.2 & 329 & 0.1 & 726.2 & 5000 & 1 & 1 \\
\hline Miscible WAG & 33 & 42 & 39 & 0.07 & 0.175 & 0.4 & 11 & 18.3 & 24 & 40 & 75 & 80 & 6000 & 9108.4 & 18500 & 194 & 229.4 & 253 & 130 & 143.3 & 1000 & 1 & 1 \\
\hline $\begin{array}{l}\text { Miscible } \\
\text { Nitrogen }\end{array}$ & 35 & 48 & 57 & 0.07 & 0.2 & 0.4 & 7.5 & 11.2 & 14 & 40 & 75.75 & 80 & 6000 & 12316.65 & 18500 & 190 & 266.6 & 325 & 0.2 & 15 & 35 & 1 & 1 \\
\hline $\begin{array}{l}\text { Immiscible } \\
\text { Nitrogen }\end{array}$ & 16 & 41 & 54 & 0 & 2256.8 & 18000 & 11 & 19.5 & 28 & 35 & 70.5 & 98.5 & 1700 & 7914.2 & 18500 & 82 & 173.1 & 325 & 3 & 1041.7 & 2800 & 1 & 1 \\
\hline Immiscible $\mathrm{CO}_{2}$ & 11 & 22 & 35 & 0.6 & 65.5 & 600 & 17 & 26.3 & 32 & 15 & 63 & 78 & 1150 & 3385 & 8500 & 82 & 124 & 198 & 30 & 217 & 1000 & 1 & 1 \\
\hline $\begin{array}{l}\text { Immiscible } \\
\text { Hydrocarbon } \\
\text { Immiscible }\end{array}$ & 22 & 38 & 48 & 0.25 & 2.1 & 4 & 5 & 13.5 & 22 & 35 & 74.5 & 83 & 6000 & 6500 & 7000 & 170 & 175 & 180 & 40 & 520 & 1000 & 1 & 1 \\
\hline $\begin{array}{l}\text { Hydrocarbon + } \\
\text { WAG }\end{array}$ & 9.3 & 34 & 41 & 0.17 & 3948.2 & 16000 & 18 & 25 & 31.9 & 35 & 70 & 83 & 2650 & 7218.71 & 9199 & 131 & 198.7 & 267 & 100 & 2392 & 6600 & 1 & 1 \\
\hline Polymer Flood & 13 & 33 & 43 & 0.4 & 111.6 & 4000 & 10.4 & 22.5 & 33 & 34 & 72 & 92 & 700 & 6610.95 & 9600 & 74 & 153.5 & 237.2 & 1.8 & 817.05 & 15000 & 1 & 0.5 \\
\hline $\begin{array}{c}\text { Alkaline- } \\
\text { Surfactant- } \\
\text { Polymer (ASP) } \\
\text { Flood }\end{array}$ & 20 & 33 & 35 & 11 & 444.4 & 6500 & 26 & 26.6 & 32 & 35 & 63.35 & 74.8 & 500 & 3117.25 & 9000 & 80 & 119.8 & 200 & 10 & 486.5 & 1520 & 1 & 0.5 \\
\hline $\begin{array}{c}\text { Surfactant }+ \\
\text { Polymer/Alkaline } \\
\text { Flood }\end{array}$ & 20 & 33 & 39 & 3 & 11.15 & 35 & 16 & 16.4 & 16.8 & 43.5 & 48 & 53 & 625 & 3095.8 & 9000 & 122 & 138.5 & 155 & 10 & 55 & 60 & 1 & 0.5 \\
\hline $\begin{array}{c}\text { In-Situ } \\
\text { Combustion }\end{array}$ & 10 & 20 & 40 & 1000 & 1200 & 5000 & 14 & 23.3 & 35 & 50 & 69.5 & 94 & 400 & 5569.6 & 11500 & 64.4 & 155.25 & 230 & 10 & 1033.25 & 15000 & 1 & 0.5 \\
\hline Steam Flood & 8 & 13.5 & 27 & 10 & 18835.65 & 5000000 & 12 & 32.2 & 65 & 35 & 66 & 90 & 200 & 1571.8 & 4500 & 10 & 175 & 350 & 1 & 2572.85 & 15000 & 1 & 0.5 \\
\hline Hot Water Flood & 8 & 16 & 27 & 10 & 3351 & 200000 & 25 & 31.2 & 37 & 15 & 62.25 & 85 & 500 & 1721 & 4500 & 60 & 98.5 & 280 & 200 & 2943 & 6000 & 1 & 0.5 \\
\hline Microbial & 12 & 26.6 & 33 & 1.7 & 2977.5 & 8900 & 12 & 19 & 26 & 55 & 60 & 65 & 1572 & 2445.3 & 3464 & 140 & 150 & 160 & 180 & 190 & 200 & 1 & 0 \\
\hline
\end{tabular}

Note:

*Sandstone

**Carbonate 
Table A2. Default Configuration of Property Classification of the Screening Criteria.

\begin{tabular}{|c|c|c|c|c|c|c|c|}
\hline Criteria/EOR Methods & $\begin{array}{l}\text { Oil API } \\
\text { Gravity }\end{array}$ & $\begin{array}{c}\text { Oil } \\
\text { Viscosity }\end{array}$ & $\begin{array}{l}\text { Reservoir } \\
\text { Porosity }\end{array}$ & $\begin{array}{c}\text { Oil } \\
\text { Saturation } \\
\text { at Initial } \\
\text { Flooding } \\
\text { Condition }\end{array}$ & Depth & $\begin{array}{c}\text { Reservoir } \\
\text { Temperature }\end{array}$ & $\begin{array}{c}\text { Reservoir } \\
\text { Permeability }\end{array}$ \\
\hline Miscible Gas Inj.: $\mathrm{CO}_{2}$ & Maximum & Minimum & Maximum & Maximum & Maximum & Minimum & Maximum \\
\hline $\begin{array}{l}\text { Miscible Gas Inj.: } \\
\text { Hydrocarbon }\end{array}$ & Average & Minimum & Maximum & Maximum & Average & Average & Maximum \\
\hline Miscible Gas Inj.: WAG & Average & Minimum & Maximum & Maximum & Average & Average & Maximum \\
\hline Miscible Gas Inj.: Nitrogen & Maximum & Minimum & Maximum & Maximum & Average & Average & Maximum \\
\hline Immiscible Gas Inj.: Nitrogen & Average & Minimum & Maximum & Maximum & Average & Average & Maximum \\
\hline Immiscible Gas Inj.: $\mathrm{CO}_{2}$ & Minimum & Minimum & Maximum & Maximum & Average & Average & Maximum \\
\hline $\begin{array}{c}\text { Immiscible Gas Inj.: } \\
\text { Hydrocarbon }\end{array}$ & Minimum & Minimum & Maximum & Maximum & Average & Average & Maximum \\
\hline $\begin{array}{l}\text { Immiscible Gas Inj.: } \\
\text { Hydrocarbon + WAG }\end{array}$ & Average & Minimum & Maximum & Maximum & Average & Average & Maximum \\
\hline Polymer & Maximum & Minimum & Maximum & Maximum & Minimum & Minimum & Maximum \\
\hline ASP & Maximum & Minimum & Maximum & Maximum & Minimum & Minimum & Maximum \\
\hline $\begin{array}{c}\text { Surfactant }+ \\
\text { Polymer/Alkaline }\end{array}$ & Maximum & Minimum & Maximum & Maximum & Minimum & Minimum & Maximum \\
\hline Thermal/Mech.: Combustion & Minimum & Minimum & Maximum & Maximum & Average & Minimum & Maximum \\
\hline Thermal/Mech.: Steam & Minimum & Minimum & Maximum & Maximum & Minimum & Minimum & Maximum \\
\hline Thermal/Mech.: Hot Water & Minimum & Minimum & Maximum & Maximum & Minimum & Minimum & Maximum \\
\hline Microbial & Average & Minimum & Maximum & Maximum & Average & Minimum & Maximum \\
\hline
\end{tabular}

Table A3. Default Configuration of the Weighting Factors $w_{i}$.

\begin{tabular}{|c|c|c|c|c|c|c|c|c|}
\hline Criteria/EOR Methods & $\begin{array}{l}\text { Oil API } \\
\text { Gravity }\end{array}$ & $\begin{array}{c}\text { Oil } \\
\text { Viscosity }\end{array}$ & $\begin{array}{l}\text { Reservoir } \\
\text { Porosity }\end{array}$ & $\begin{array}{c}\text { Oil } \\
\text { Saturation } \\
\text { at Initial } \\
\text { Flooding } \\
\text { Condition }\end{array}$ & Depth & $\begin{array}{c}\text { Reservoir } \\
\text { Temperature }\end{array}$ & $\begin{array}{c}\text { Reservoir } \\
\text { Permeability }\end{array}$ & $\begin{array}{c}\text { Reservoir } \\
\text { Formation } \\
\text { Type }\end{array}$ \\
\hline Miscible Gas Inj.: $\mathrm{CO}_{2}$ & 3 & 1 & 1 & 1 & 1 & 1 & 1 & 1 \\
\hline $\begin{array}{l}\text { Miscible Gas Inj.: } \\
\text { Hydrocarbon }\end{array}$ & 1 & 1 & 1 & 1 & 1 & 1 & 1 & 1 \\
\hline Miscible Gas Inj.: WAG & 1 & 1 & 1 & 1 & 1 & 1 & 1 & 1 \\
\hline Miscible Gas Inj.: Nitrogen & 1 & 1 & 1 & 1 & 1 & 1 & 1 & 1 \\
\hline $\begin{array}{l}\text { Immiscible Gas Inj.: } \\
\text { Nitrogen }\end{array}$ & 1 & 1 & 1 & 1 & 1 & 1 & 1 & 1 \\
\hline Immiscible Gas Inj.: $\mathrm{CO}_{2}$ & 3 & 1 & 1 & 1 & 1 & 1 & 1 & 1 \\
\hline $\begin{array}{c}\text { Immiscible Gas Inj.: } \\
\text { Hydrocarbon }\end{array}$ & 2 & 1 & 1 & 1 & 1 & 1 & 1 & 1 \\
\hline $\begin{array}{l}\text { Immiscible Gas Inj.: } \\
\text { Hydrocarbon+WAG }\end{array}$ & 1 & 1 & 1 & 1 & 1 & 1 & 1 & 1 \\
\hline Enh. Waterflooding: Polymer & 1 & 1 & 1 & 1 & 3 & 3 & 1 & 1 \\
\hline Enh. Waterflooding: ASP & 1 & 1 & 1 & 1 & 3 & 3 & 1 & 1 \\
\hline $\begin{array}{l}\text { Enh. Waterflooding: } \\
\text { Surfactant+P/A }\end{array}$ & 1 & 1 & 1 & 1 & 3 & 3 & 1 & 1 \\
\hline Thermal/Mech.: Combustion & 3 & 3 & 1 & 1 & 3 & 1 & 1 & 1 \\
\hline Thermal/Mech.: Steam & 3 & 3 & 1 & 1 & 3 & 1 & 1 & 1 \\
\hline Thermal/Mech.: Hot Water & 3 & 2 & 1 & 1 & 3 & 1 & 1 & 1 \\
\hline Microbial & 1 & 1 & 1 & 1 & 1 & 3 & 1 & 1 \\
\hline
\end{tabular}




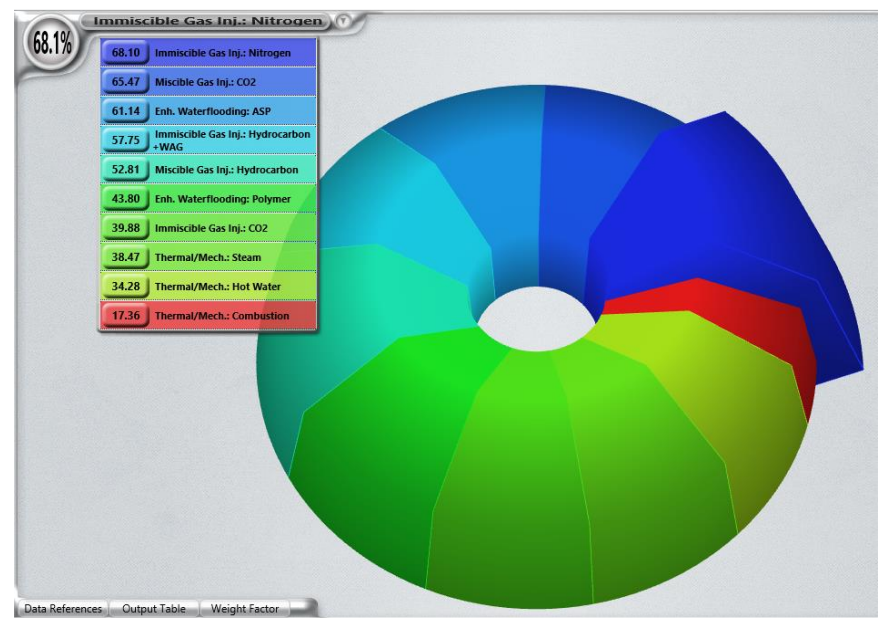

Figure A1. Results of Screening Study of Minas Field

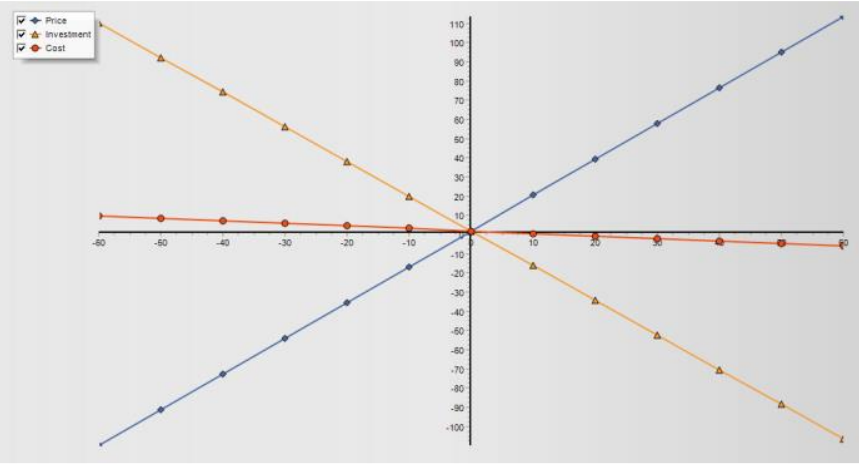

(i)

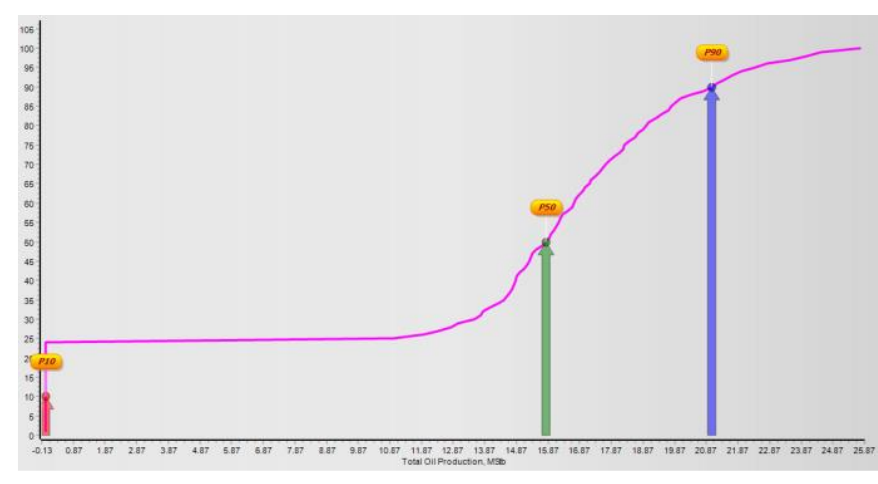

(ii)

Figure A3. Results from (i) Economic and (ii) Risk Evaluation Study of Minas Field

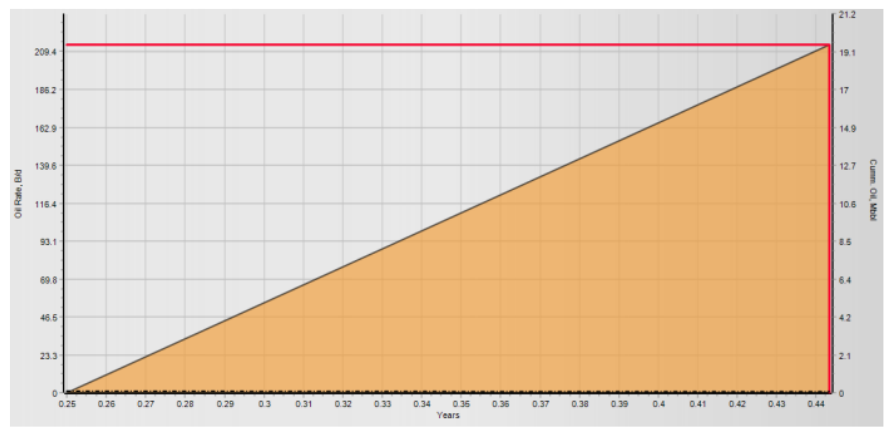

(i)

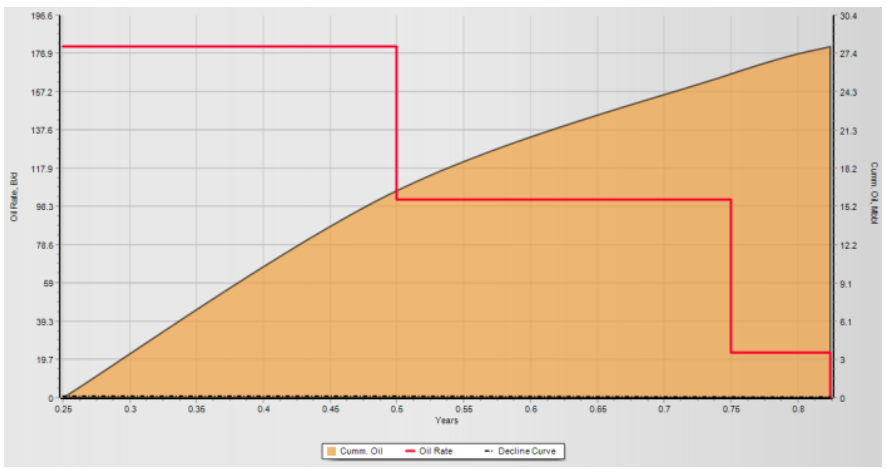

(ii)

Figure A2. Results of Surfactant-Polymer Predictive Model for Minas Field, (i) Original Scenario, (ii) Optimized Scenario

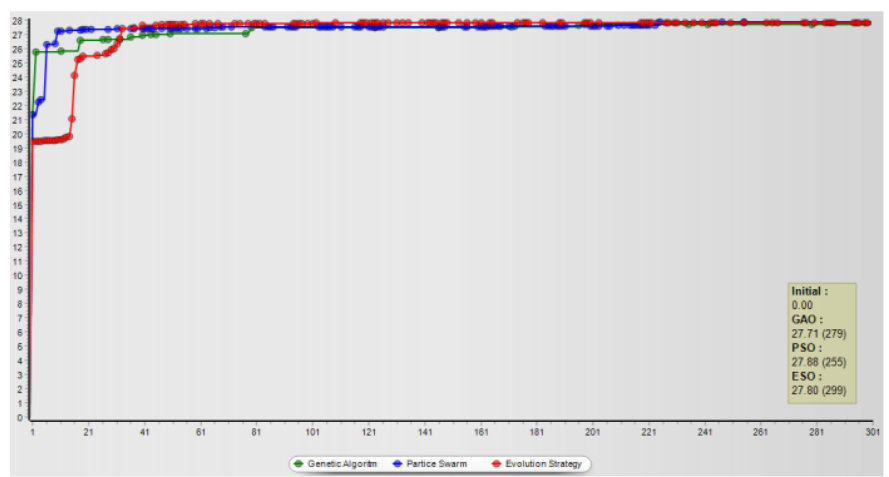

Figure A4. Results of Optimization Assessment of Minas Field 